\title{
Creating A Conducive Classroom Environment: Classroom Management Is The Key
}

Bev Findley, (E-Mail: bfindley@eiu.edu), Eastern Illinois University Dale Varble, (E-Mail: dvarble@indstate.edu), Indiana State University

\begin{abstract}
Creating a classroom environment which is conducive to learning is one of the most important things a teacher can do. This becomes even more crucial as students enter classrooms with their cell phones, pagers, and beepers. Additionally, many students are tardy for class, leave early, or may not appear in class on numerous occasions. Therefore, classroom management takes on greater significance at the university level. Effective classroom management starts at the first class meeting. Everything a teacher does on Day One will set the stage for the procedures, routines, and expectations throughout the course. Having a detailed syllabus, outlining requirements for the course, defining expectations for attendance and participation, and explaining the "rules of the road" are just the beginning of how a teacher models expected behavior of the students. This paper provides successful strategies used in university classrooms and presents a review of literature on effective university classroom management practices.
\end{abstract}

\section{INTRODUCTION}

$\mathcal{G}$

oing off to college is an exciting time for the students and for their parents. Moving away from home for many students will be a new experience, as will the independence many of them will find. Parents are concerned that their children do well in school, meet new friends, and have an enjoyable experience. Students will have those same concerns, but may not have them in the same priority. College offers students newfound independence and less-directive classes than in high school. Therefore, some students may not understand the importance of class attendance and participation, of time management, and of common-sense courtesies which should be extended in the university classroom. Many students believe that the classroom door is a revolving one, allowing them to come to class late, leave early, or take breaks within the class period. Students often answer cell phones, beepers, and pagers in class. Additionally, knowledge of the fact that laws regarding confidentiality prohibit professors from notifying the students' parents of potential problems enables students to continue behaviors that will set them up for failure at the end of the course. "The most important action an effective teacher takes at the beginning of the year is creating a climate for learning" (Blegan, as cited in "Creating a Climate for Learning: Effective Classroom Management Techniques," 2002). Therefore, it is crucial that professors begin classroom management strategies on the first day of class in order to set the tone for the remainder of the session.

\section{CLASSROOM MANAGEMENT DEFINED}

"Classroom Management means more than just maintaining strict and rigid control over the class and its content - it means establishing a comfortable environment that allows everyone to learn and participate freely" (Penn State Teacher II, 1997 , I 2). Classroom management is the procedures and routines that allow teachers to teach and students to learn (Wong, as cited in "Speaking of Classroom Management—An Interview with Harry K. Wong," 1999). According to Wong, classroom management has a tremendous impact on student achievement. He does not address class rules, because a procedure is not a rule; it is a task. Rather than having rules which are either upheld or broken, Wong stresses procedures, which explain the manner in which tasks are accomplished and the rationale for having them. Professors must explain the expected procedures. Once these procedures become automatic to the 
students, without teacher explanation, they have become routines. By establishing procedures and routines, students understand the "mechanics" of the classroom operation and are then free to do the work of the class.

\section{Day One}

"The very first day, the very first minute, the very first second of school, teachers should begin to structure and organize their classrooms, to establish procedures and routines" (Wong, as cited in "Speaking of Classroom Management-An Interview with Harry K. Wong," 1999). Professors do this by presentation of themselves through their appearance, their punctuality, their organizational skills, their syllabi, and their use of materials and technology.

\section{Appearance}

Although image is not everything, it is certainly an important issue. This is the first impression students will have of their professors. Professors should dress at least one step above their clients (students). Professional dress, even "business casual" dress, is important in establishing credibility. Professors need to understand that their professional image says, "I mean business" ("First Impression Management: Dressing for Success Training,” 2004).

\section{Punctuality}

When professors arrive early for class, they are able to start the class ON TIME. Professors should not wait for students. They should role model the expectation for punctuality. Additionally, they should explain when and if breaks will be taken (if the class lasts for an extended time). Professors should always end class on time. If students start packing bags early, professors should remind students that this is distracting and although they will not be held later than the expected time, they do need to be present and attentive for the required time.

\section{Organizational Skills}

Professors set the stage for expected behaviors by demonstrating their own organizational skills. Is everything "ready to go" at the first class meeting? Or is much class time lost looking for class lists, important announcements, distributing handouts, etc.? The level of organization demonstrated by professors may be translated into the amount of credibility and respect given to those professors. Poor organization may be interpreted by the students as the professors do not have their acts together, so therefore, they will not be too harsh on the students if they demonstrate the same disorganization. However, professors who have their fingers on the pulse of the class will be given more credibility and more respect, simply because students know that these professors are cognizant of everything going on in the classroom.

One strategy for organization is to have folders with each student's name on it (names are obtained from student rosters on the mainframe). Included in each folder are the syllabus and all handouts to be used throughout the course. The last page of the syllabus is an attendance sheet listing each class meeting date which students must initial on each day of class. This sheet can be easily removed from the remainder of the syllabus and becomes a permanent part of the folder. The professors personally hand each student the folder as the students enter the room. At first professors may have to ask their names; after a few meetings professors will become more familiar with each student and start learning names and faces. Students remove all handouts from the folder and are told to bring them to class each time thereafter. Students sign the attendance sheet and put it back in the folder. At end of class, each student returns the folder to a file box upon leaving the room. Professors can then check attendance and record it by initialing the attendance sheet. It is important for professors to know their students' names. "If the class is large, they should learn as many names as possible [or perhaps enlist the aid of graduate assistants, if possible]. Students are more likely to cause problems if they are anonymous in the classroom. When professors use students' names, they give the students a sense of personal responsibility for the class" (Penn State Teacher II, 1997, I 14). The attendance sheet/folder procedure streamlines taking attendance, distributing handouts, and learning students' names while also sending a strong message that the professors will personally greet students entering class, so no one can "hide" in class or send a friend to take notes. 


\section{Syllabus}

Professors can use the syllabus as a motivational tool. Students must see "education as personally relevant to their interests and goals" (McCombs, as cited in "Capturing and Directing the Motivation to Learn,” 1998, 1). Students are getting ready for their profession, whether it is in business, education, health, liberal arts, etc. In each case, there will be job descriptions for them. Professors can use their syllabus as the students' job description. For example, as part of the students' "employment," professors will be looking at their attendance, punctuality, participation, and projects. As in a job, students will have formative and summative evaluations. Professors provide formative evaluation by doing all they can to give feedback throughout the course (job) and helping students make corrections that need to be made as well as affirming the strengths that they exhibit. Additionally, throughout the course, professors will provide grades on projects, feedback on class discussions, notification of excessive absences or tardies, and office hours for conversations with the students.

At the end of the course, professors will provide summative evaluations of the students' work and will decide their future as "employees" of the organization. In other words, students will be retained or dismissed. Retention means their work was satisfactory, and their grade would reflect that. Dismissal means their work was unsatisfactory, and their grade would reflect that as well.

The syllabus can also explain the expectations for class attendance and participation. Students need to understand that they can attend class without participating, but they cannot participate unless they attend. "Presence is more than just being there" (Forbes, as cited in "ThinkExist Quotations, 2004). Again, the analogy of the job description and expectations for successful employment can be used. Most professions require workers to collaborate with colleagues. Very few of us work in isolation. Students need to attend class to be a part of the network. It is not just the ideas put forth by the professors that are important, but also the comments and ideas by fellow students. Attendance and participation are the precursors to good networking. Professors may want to REWARD attendance and participation by allotting points, rather than DEDUCTING points for non-attendance.

As mentioned earlier, networking is an important tool used by many successful professionals. The classroom serves as a foundation for networking now as students and in the future as professionals. Students need to be TODAY the kind of employee they want to hire when they get in the position to do so. Students need to be reminded that they are building their reputations NOW as students. Faculty will be asked to write letters of recommendation in the future. The professors will remember the outstanding students. They will remember the terrible students. They may not remember the silent students who never contributed to discussions. The letters that are written will certainly reflect the opinion that professors had of the students. Fellow students will also remember their classmates. Those in the same field may be in a position to hire employees one day. If the non-attentive, non-participative student applies, will he get hired by his classmate who remembers him? Will he even get referred for a job by classmates? "Uninspired people rarely do inspired work" (Sanborn, 2004, p. 74). How will classmates remember each other from college days? Students need to remember that they are building their reputations NOW!

What else does the syllabus do? The syllabus is the "contract" between the student and the professor-

- What the professor will provide
Hhat the student will provide
How work will be evaluated
- What standards (accreditation or university goals) will be met throughout the course
- $\quad$ Ahat resources are available to the student
- $\quad$ Wentact information for the Office of Disabilities
-

The syllabus should set the students up for success. Professors do not want the students to fail, but do they set the students up for success? Students are much more appreciative and receptive to complying when they are fully 
informed and understanding of exactly what is expected of them. This can be done by using Ken Blanchard's SMART goals (as cited in "Setting SMART Goals, 2004).

Directions for assignments and projects should be:

\begin{tabular}{ll} 
- & Specific \\
- & Aeasurable \\
- & Attainable \\
- & Relevant \\
\hline
\end{tabular}

What will the professor provide, as noted in the syllabus?

- $\quad$ The major topics that will be covered at each class meeting

- $\quad$ These can then be identified as to which accreditation standard or university goal that is being met.

- $\quad$ All assignments and projects and timelines for each, with detailed expectations for each assignment.

- $\quad$ The points possible on each assignment.

- $\quad$ The grading scale.

- $\quad$ The attendance/participation policy.

- $\quad$ Office hours and other means by which students may contact the professor (e-mail or home phone if the professor is agreeable to that).

The syllabus should also address expected behaviors in the classroom. As noted in the Baruch College Faculty Handbook:

Most students appreciate having limits clearly articulated and enforced. Those limits can include: phones and beepers turned off; no leaving class for calls; a request that students visit bathrooms before or after class, not during; no talking while the instructor is talking; no sleeping, questions to be directed to the instructor; no reading of materials unrelated to the class; no use of laptop computers other than for taking notes. (\$ 2)

Vandergrift notes in her own syllabus that:

All teaching grows out of the teacher's personal and professional values which lead to assumptions and ultimately to teaching practices. Students often spend most of a semester trying to decipher a faculty member's unstated assumptions. Clarifying those assumptions in advance might be useful in focusing the intellectual energies of the teacher and the students. (2004, Objectives section, ๆ 2).

\section{After Day One}

Effective classroom management can be promoted through good communication. "Faculty can remain respectful and manage student behavior through effective communication" (Morrissette, 2001, Effective Communication Skills section, $\mathbb{\uparrow} 1$ ). He offers the following suggestions to enhance acceptable behaviors in class:

- $\quad$ Respectfully listen to students

- $\quad$ Serve as role models for respect and understanding

- $\quad$ Speak with the students rather than speaking at the students.

- $\quad$ Students who sense that faculty are genuinely trying to understand and honor their perspective are probably less likely to feel disregarded or belittled in front of their peers (Morrissette, 2001, Effective Communication Skills section, ๆ 1 ).

Research shows that students who feel a sense of connection have a much higher rate of success (in and out of the classroom) (Astin, as cited in "FISH! For College, Frequently Asked Questions section, I 5). The best 
classroom management is achieved when students "feel welcomed, feel involved, and, most of all, valued.” (Fish! For College, Frequently Asked Questions section, \ 5). Therefore, acknowledging students by name, reinforcing positive behaviors, redirecting off-task behaviors, modeling a sense of humor, and genuine concern for students all contribute to students' sense of connection and ultimately to success.

\section{CONCLUSION}

Classroom management is more important today than ever. With the availability of increased methods of communication within the classroom that can be distracting to the learning environment, the problems may be more than simply passing notes in class. What professors do BEFORE the class meeting (e.g., preparation of materials) will heavily impact what occurs DURING the class. Perhaps the first minute of the class meeting is the most important period of time for establishing classroom management. During this time, students have their first impression of their professor and the learning environment. Classroom management is also identifying the norms by which students can succeed in a learning environment. Finally, procedures (and their explanation to students) allow professors to be proactive rather than reactive to the classroom environment. “...Prevention is often the key to avoiding difficult situations in the classroom” (Penn State Teacher II, 1997, ף 2).

\section{REFERENCES}

1. The Baruch College Faculty Handbook (2003). Classroom Management. Retrieved July 20, 2004, from http://www.baruch.cuny.edu/facultyhandbook/classroom_mgt.htm.

2. Capturing and directing the motivation to learn (1998, Fall). Speaking of Teaching, 10, 1.

3. Creating a climate for learning: Effective classroom management techniques (updated 2002, February 28). Retrieved July 29, 2004, from http://www.education-world.com/a_curr/curr155.shtml/

4. First impression management: Dressing for success training (2004). Retrieved August 20, 2004, from http://www.firstimpressionmanagement.com/professional_image.htm

5. FISH! For college (2004). Retrieved July 27, 2004, from http://www.charthouse.com/ffc/faq.asp

6. Morrissette, P.J. (2001, May14). Reducing incivility in the university/college classroom. International Electronic Journal for Leadership in Learning, 5. Retrieved August 20, 2004, from http://www.ucalgary.ca/ iejll/volume5/morrissette.html

7. The Penn State Teacher II: Learning to Teach; Teaching to Learn (1997). Appendix A: Managing the classroom and relating to students. Retrieved August 8, 2004, from http://psu.edu/celt/PST/managing.html/

8. $\quad$ Sanborn, M . (2004). The Fred Factor. New York: Random House, Inc.

9. $\quad$ Setting SMART goals (updated 2004, May 26). Retrieved August 29, 2004, from http://www.uwec.edu/career/Students/Explore/Smart_Goals.htm

10. Speaking of classroom management-An interview with Harry K. Wong (updated 1999, September 13). Retrieved July 29, 2004, from http://www.education-world.com/a_curr/curr161.shtml/

11. ThinkExist quotations (2004). Retrieved August 29, 2004, from http://en.thinkexist.com/quotes/malcolm_s. forbes/

12. Vandergrift, K. (2004). University Teaching and Life in Academe. Retrieved July 29, 2004, from http://www.scils.rutgers.edu/ kvander/Syllabus/academicteaching.html 
NOTES 